\title{
Animal Models of Diabetes Mellitus for Islet Transplantation
}

\author{
Naoaki Sakata, ${ }^{1}$ Gumpei Yoshimatsu, ${ }^{1}$ Haruyuki Tsuchiya, ${ }^{1}$ \\ Shinichi Egawa, ${ }^{2}$ and Michiaki Unno ${ }^{1}$ \\ ${ }^{1}$ Division of Hepato-Biliary-Pancreatic Surgery, Department of Surgery, Tohoku University Graduate School of Medicine, \\ 1-1 Seiryo-machi, Aoba-ku, Sendai, Miyagi 980-8574, Japan \\ ${ }^{2}$ Division of International Cooperation for Disaster Medicine, International Research Institute of Disaster Science, Tohoku University, \\ Sendai, Miyagi 980-8574, Japan \\ Correspondence should be addressed to Naoaki Sakata,n-sakata@surg1.med.tohoku.ac.jp
}

Received 19 November 2012; Accepted 12 December 2012

Academic Editor: Tomohiko Sasase

Copyright (c) 2012 Naoaki Sakata et al. This is an open access article distributed under the Creative Commons Attribution License, which permits unrestricted use, distribution, and reproduction in any medium, provided the original work is properly cited.

Due to current improvements in techniques for islet isolation and transplantation and protocols for immunosuppressants, islet transplantation has become an effective treatment for severe diabetes patients. Many diabetic animal models have contributed to such improvements. In this paper, we focus on 3 types of models with different mechanisms for inducing diabetes mellitus (DM): models induced by drugs including streptozotocin (STZ), pancreatomized models, and spontaneous models due to autoimmunity. STZ-induced diabetes is one of the most commonly used experimental diabetic models and is employed using many specimens including rodents, pigs or monkeys. The management of STZ models is well established for islet studies. Pancreatomized models reveal different aspects compared to STZ-induced models in terms of loss of function in the increase and decrease of blood glucose and therefore are useful for evaluating the condition in total pancreatomized patients. Spontaneous models are useful for preclinical studies including the assessment of immunosuppressants because such models involve the same mechanisms as type $1 \mathrm{DM}$ in the clinical setting. In conclusion, islet researchers should select suitable diabetic animal models according to the aim of the study.

\section{Introduction}

Islet transplantation is a cell replacement therapy for severe diabetes mellitus (DM), including type $1 \mathrm{DM}$, that has a long history. In 1967, Lacy and Kostianovsky established a method for isolating islets from rat pancreas using collagenase [1]. Their group also first succeeded in islet intraportal transplantation and reversed diabetes in a rat model [2]. In the clinical setting, the first successful trial of human islet allotransplantation was performed at the University of Pittsburgh in 1990, and five patients achieved an insulinfree condition after islet transplantation [3]. Shapiro and colleagues could significantly improve the outcome of islet transplantation using the "Edmonton Protocol" based on multiple transplantations with a steroid-free immunosuppressive regimen in 2000 [4]. Recent data of clinical islet transplantation revealed that $50 \%$ of the patients achieved insulin independence for 5 years [5]. This represents great progress since the rate of being insulin-free was only $10 \%$ in the late 1990s [6]. Many studies have been done to improve the success of islet transplantation and will continue to be done in the future.

Animal models of DM have contributed much to islet research and to evaluations of isolated human islets for clinical islet transplantation. Good control of blood glucose is the major goal in islet research. Assessments of drugs for improving islet function and immunosuppressants for protecting transplanted islets from the immune system are good examples of progress toward this goal. We introduce some animal models of DM in this paper, and clarify why and how the models should be used, based on our experience and publications by others.

\section{Animal Models of DM for Islet Research}

2.1. History of Animal Models of DM. Animal experiments have a long history in the field of diabetic research, including 
islet research. Animal models of DM are classified as spontaneous or secondary (drug-induced, pancreatectomized, and biomolecular method). The earliest animal model of DM was a pancreatomized dog that was used to evaluate the intestine function in the 1880s, and many pancreatomized animal models (rabbit and dog) have been used for diabetic studies including the purification of insulin [7].

While the pancreatomized model was established approximately 100 years ago, drug-induced models also have a long history. Alloxan is a pyrimidine derivative that was synthesized by Wöhler in 1838 [8], and it was considered a representative drug for diabetes by inducing necrosis of the endocrine beta cells in 1940s $[9,10]$. The first report of streptozotocin (STZ: N-nitroso derivative of glucosamine), a most convenient drug for inducing diabetes, was published in 1963 [11]. STZ was used as chemotherapeutic agent for cancer based on its inhibition of DNA synthesis and, like alloxan, has been used for making animal models of DM [12].

Spontaneous diabetic animal models were first described in the 1970s. A nonobese diabetic (NOD) mouse, known as a type $1 \mathrm{DM}$ model, was established by Makino's group from female mice derived from a JcI-ICR strain that developed cataracts [13]. The biobreeding (BB) rat, which was established by the Bio Breeding Laboratory and described in 1974 [14], is also an animal model of type 1 DM. Islets of these models suffered from autoimmune attack by T cells, B cells, macrophages, and natural killer cells, inducing insulitis and finally leading to islet loss [15-19]. This mechanism reflects the onset of type $1 \mathrm{DM}$, and these models have been utilized for many studies about this disease. Drug-induced diabetic models are similar to spontaneous type $1 \mathrm{DM}$ models in terms of the loss of islets and deficiency of internal insulin, but the mechanism is different: the involvement of autoimmunity is a feature of the latter type.

On the other hand, there are many animal models of type 2 DM including ob/ob mice in 1949 [20], $d b / d b$ mice in 1974 [21], fa/fa (Zunkar) rats in 1989 [22], Goto-Kakizaki rats in 1976 [23], and Otsuka Long-Evans Tokushima fatty (OLETF) rats in 1992 [24]. Many of them are animal models of obesity, and they contribute to clarifying the correlationship between obesity and type 2 DM. ob/ob mice and $f a / f a$ rats have hyperinsulinemia with insulin resistance when they gain weight [7], reflecting the condition of obesity in human. Recently, it was clarified that a deficiency of or resistance to leptin, a $16 \mathrm{kDa}$ protein hormone that plays a key role in regulating energy intake and energy expenditure, caused the development of obesity in $o b / o b$ mice (this is a model of ob gene deficient) [25], fa/fa rats, and $d b / d b$ mice (which are leptin-resistant models due to a mutation of the leptin receptor) $[26,27]$.

Transgenic animal models have been used in diabetic research since the 1990s, and such models have revealed the roles of many genes that are related to DM including type 1 and $2 \mathrm{DM}$. Insulin receptor gene knockout mice have severe hyperglycemia and neonatal death by ketoacidosis [28]. Moreover, insulin receptor substrate (IRS), which is known to be an important ligand in the insulin response, has a different function according to the type of animal. For example, IRS1 gene knockout mice have mild insulin resistance with normoglycemia [29], while IRS2 gene knockout mice suffer from severe hyperglycemia with insulin resistance and reduction of the $\beta$ cell mass $[30,31]$. These findings make understandable the fact that some type 2 DM patients have normoglycemia or mild hyperglycemia, while others have severe hyperglycemia.

Many animal models of DM have been developed and are chosen depending on the purpose of the study (Table 1). In islet transplantation research, STZ-induced diabetic animals are mainly used, while spontaneous and pancreatomized models are also available.

\subsection{STZ-Induced Diabetic Model for Islet Transplantation}

2.2.1. Background. STZ, a white powder with a molecular weight of $265.221 \mathrm{~g} / \mathrm{moL}$, is a glucosamine-nitrosourea compound. STZ causes toxicity to cells by impairing DNA and by other mechanisms. One is the activation of poly-ADP ribosylation, which is likely more important for the induction of DM than the DNA damage [32]. STZ is similar to glucose insofar as it is transported into $\beta$ cells by the glucose transport protein GLUT2, but is not recognized by the other glucose transporters. Thus, $\beta$ cells have relatively high levels of GLUT2 $[33,34]$. This explains the specific toxicity of STZ for $\beta$ cells. In the early 1970s, Lacy and his collaborators first performed experimental islet transplantation to rats with STZ-induced DM $[35,36]$. STZ was applied not only to rats but also many other kinds of mammals including mouse [37], monkey [38], and dog [39]. Since then, STZ-induced diabetic models have been available for islet research.

2.2.2. Dose and Method of Inducing DM. The dose of STZ is varied according to the animal species and strain (Table 2) [40-87]. For example, mice required higher doses of STZ for inducing DM compared with other animals. While in ICR mice DM can be induced with comparatively lower doses $(90-150 \mathrm{mg} / \mathrm{kg})$, C57BL/6 mice need approximately $200 \mathrm{mg} / \mathrm{kg}$ dose of STZ [40, 42-48]. Immunodeficient mice tend to need less dose of STZ than other wild-type strains. For example, NOD-SCID mice are induced DM with 120 $140 \mathrm{mg} / \mathrm{kg}$ dose of STZ [88-90]. STZ injection is done with two methods: a single injection and low dose multiple injection. Continuous low dose injection has been used in many studies, especially these employing rodents [49-57]. The merit of single injection is its convenience (only 1 injection), but the diabetic model induced by this method is unstable in terms of the diabetic condition, and sudden death is caused in approximately $10 \%-20 \%$ of the animals due to the elevation of blood glucose and the toxicity of STZ. On the other hand, the low dose multiple injection method can achieve hyperglycemia with no or few dead cases [91]. It is considered that the low dose multiple injection model is superior to single injection model in terms of safety. Intraperitoneal (i.p.) injection tends to be employed for rodents while intravenous (i.v.) injection used for larger animals, because i.p. is easier than i.v. in rodents while i.v. has the merit of direct injection of STZ without loss of STZ 
TABLE 1: Animal models of DM.

\begin{tabular}{lcc}
\hline Characters & Name & Species \\
\hline Type 1 DM & NOD & Mouse \\
Spontaneous model & BB & Rat \\
\hline Type 2 DM & $o b / o b$ & Mouse \\
& $d b / d b$ & Mouse \\
& fa/fa & Rat \\
Obesity model & Goto Kakizaki & Rat \\
& OLETF & Rat \\
\hline Type 1 and 2 DM & Alloxan & $*$ \\
Drug-induced model & STZ & $*$ \\
\hline Pancreatic DM & & $* *$ \\
Pancreatomized model & Pancreatectomy & \\
\hline Others & Insulin knockout & Mouse \\
& IRS1 knockout & Mouse \\
Transgenic animal model & IRS2 knockout & Mouse \\
\hline * All experimental animals are available. & \\
**All experimental animals are available but larger animals tend to be used.
\end{tabular}

in comparison with i.p. Therefore i.v. injection can induce diabetes at a lower dose of i.p. because more time is required to absorb STZ with i.p., and some of the STZ is inactivated before absorption. The dose of STZ for i.v. is approximately $90 \%$ of that for i.p. in previous publications (Table 1). Citrate buffer at $\mathrm{pH} 4.5$ has been used as a solvent in many studies because STZ remains stable at low pH (Table 2), but there is no problem with using normal saline if STZ is used immediately after dissolving.

\subsubsection{Our Method of DM Induction Using STZ and Discussion} of STZ-Induced DM Model for Islet Transplantation. STZ (Sigma-Aldrich Co. LLC., St. Louis, MO, USA) must be stored in a freezer (under $-20^{\circ} \mathrm{C}$ condition) because of its instability. To prevent inactivation, we divide $20 \mathrm{mg}$ of STZ into $1.5 \mathrm{~mL}$ centrifuge tubes before using. Some of the divided STZ (3-4 mice per tube), $1 \mathrm{~mL}$ syringe with 29gauge needle, an ice box with crushed ice, the solvent (citrate buffer solution, $0.09 \mathrm{M}$, pH4.8 (Sigma-Aldrich) or normal saline), and 18-gauge needles are prepared for the treatment (Figure 1(a)). The STZ tubes should be placed on ice until dissolution. At first, the mice are marked on the tail and measured for body weight, and then the final volume of STZ solution is decided. We induce DM with STZ at $200 \mathrm{mg} / \mathrm{kg}$ body weight. $20 \mathrm{mg}$ of STZ is dissolved with $1 \mathrm{~mL}$ of solvent (the concentration is $20 \mathrm{mg} / \mathrm{mL}$ ). We crushed the larger clusters of STZ with a 18-gauge needle and then dissolved it by shaking gently (Figures $1(\mathrm{~b})-1(\mathrm{e})$ ). To induce DM for a mouse with $20 \mathrm{~g}$ of body weight, for example, $200 \mu \mathrm{L}$ of STZ solution is necessary. STZ solution should be used as soon as possible after dissolving, because the diabetogenic activity of STZ is decreased in the solvent [92]. Injection should be done within 10 minutes after the dissolution. In the case of i.p., the STZ solution is injected via the lower abdomen with care taken to prevent organ injury (Figure $1(\mathrm{f})$ ). In the case of i.v., STZ solution is injected via a tail vein. Tail veins are located at the dorsal and left and right sides of the tail. After dilating the tail vein by warming, the 29-gauge needle is inserted in the upper $1 / 2 \sim 1 / 3$ of the tail and the STZ solution is injected slowly (Figures 2(a) and 2(b)). After finishing the injection, the needle is removed while pressing part of the puncture with thumb to prevent leakage of the STZ solution (Figure 2(c)). After the injection of STZ, we check blood glucose every day, and mice with over $350 \mathrm{mg} / \mathrm{dL}$ of blood glucose at two consecutive measurements are considered DM mice suitable for islet transplantation. Our data revealed that the effect of $160 \mathrm{mg} / \mathrm{kg}$ of STZ injection via i.v. was equal to that of $200 \mathrm{mg} / \mathrm{kg}$ of STZ injection via i.p. in blood glucose level (Figure 3). The rates of achieving hyperglycemia (over $350 \mathrm{mg} / \mathrm{dL})$ in BALB/c mice were 58.8\% (33.3\%-70\%, $n=$ $36)$ by i.p. method and $81.8 \%(80 \%-83.3 \%, n=22)$ by i.v. method. In our opinion, diabetic models for islet transplantation studies should have severe hyperglycemia because mice with mild hyperglycemia (under $300 \mathrm{mg} / \mathrm{dL}$ ) can show normoglycemia depending on the measurement time, and it can be difficult to determine whether the normoglycemia is due to the original pancreatic endocrine function of the recipient mice or due to the islet transplantation. Fasting is not necessary, but the measurements for blood glucose should be done at the same time to prevent the influence of ingestion. We measure the blood glucose from 6 to 10 AM. The afternoon is excluded because the blood glucose in the afternoon tends to be higher than in the morning. We defined normoglycemia as under $200 \mathrm{mg} / \mathrm{dL}$ blood glucose because it is the upper range of blood glucose in normal (untreated) mice.

\subsection{Pancreatomized Diabetic Model for Islet Transplantation.} Pancreatomized animals are one of the oldest models for DM. This model was considered to be and used as a type 1 DM model because of the elimination of the pancreatic $\beta$ cells. The difference between this model and type $1 \mathrm{DM}$ is the stability of the blood glucose: the type $1 \mathrm{DM}$ model has a deficiency of insulin release but preservation of other hormonal functions that act to increase the blood glucose (i.e., glucagon). Pancreatomized diabetic animals have been used as islet autotransplantation models. Minnesota group performed pancreatectomy and islet autotransplantation in pigs in 1976 [93]. This group also performed islet autotransplantation of pancreatomized dogs and succeeded in achieving normoglycemia at the same time [39]. After their success, many experimental models of total pancreatectomy with islet autotransplantation using dogs were published in the 1970s and proved the effectiveness of the treatment [94-96]. These findings contributed to clinical trials of total pancreatectomy with islet autotransplantation for chronic pancreatitis [97]. Large pancreatomized animal models have also been used for the evaluation of cryopreserved islets [98-101] and optimal transplant sites [102-107]. Large pancreatomized diabetic animal models have been used 
TABLE 2: Dose of STZ.

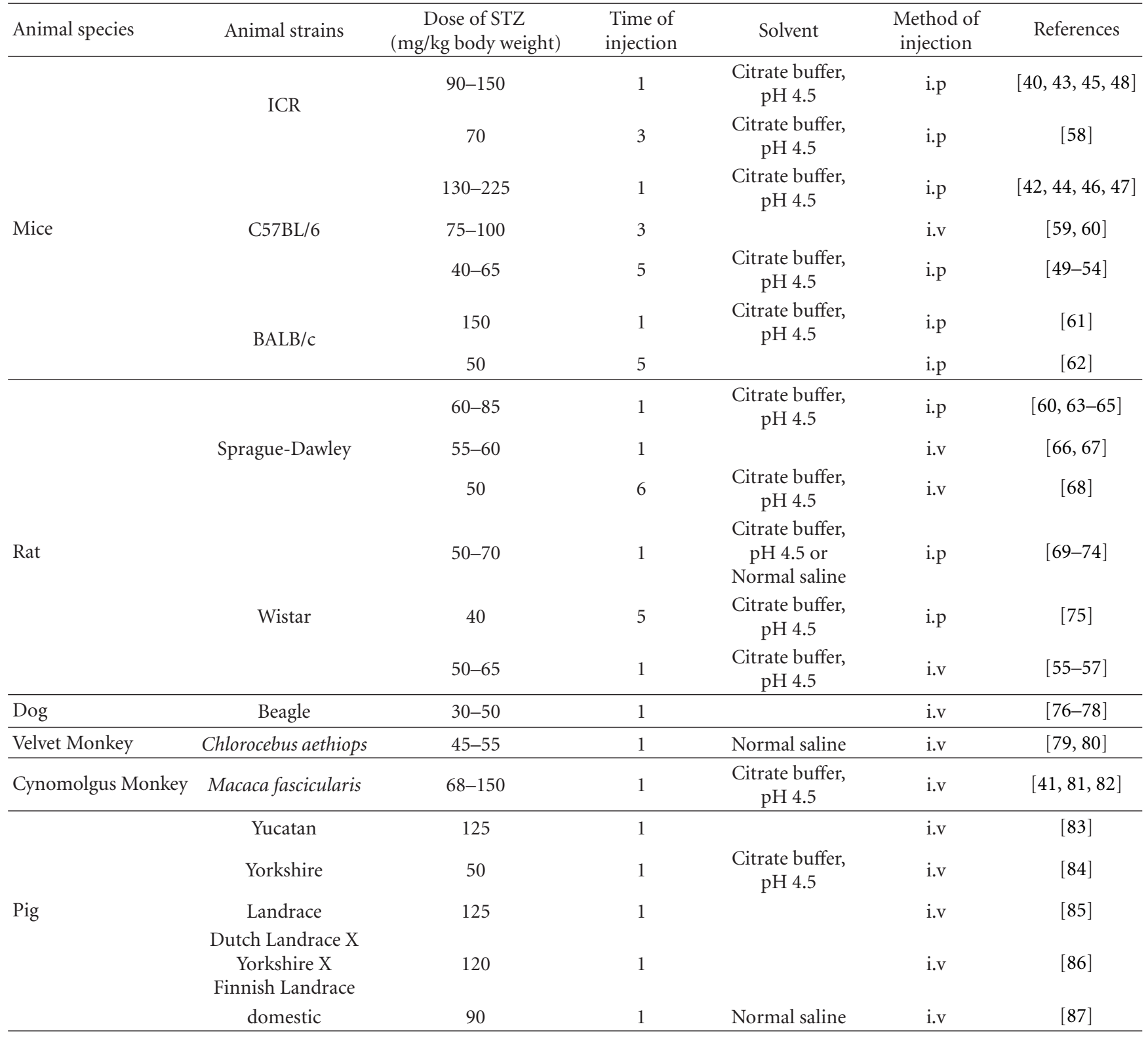

not only for islet autotransplantation studies but also for allotransplant studies. Many groups examined the usefulness of immunosuppressants including cyclosporine using islet allotransplanted dog [108-110] and pig models [111]. Pancreatomized diabetic large animals were also used for studies about bioartificial pancreas (i.e., islet encapsulation technology using high molecular compound to prevent from immune attack) in allo- and xenotransplantation [112118]. Large pancreatomized animal models for islet transplantation, including pig, dog, and monkey, are considered preclinical models and tend to be selected for evaluating some treatments in the clinical setting.

One of the recent uses of pancreatomized models is to assess $\beta$ cell regeneration after pancreatectomy. Pancreatectomy over $70 \%$ induces some pancreatic regeneration-related factors like pancreatic and duodenal homeobox 1 (PDX1) and neurogenin-3 (Ngn3), which contribute to the regeneration of $\beta$ cells in rodent models [119-121]. Recently, Jung and colleagues revealed that the regeneration of $\beta$ cells could be detected in the remnant pancreas of $\mathrm{BALB} / \mathrm{c}$ mice with $70 \%$ pancreatectomy, and the effect of regeneration was more prominent in pancreatomized mice with islet autotransplantation [122]. It is interesting that islet masses in remnant pancreas were increased with greater expression of Ngn3 and BrdU (a proliferation marker) and lower expression of TUNEL (an apoptosis marker) in pancreatomized mice with islet autotransplantation compared to pancreatomized mice without transplantation. They concluded that insulin released from transplanted islets has a role in the induction of islet proliferation and antiapoptotic effects on remnant islets. Pancreatomized animal is an old diabetic model, but is still important and useful for preclinical trials on islets 


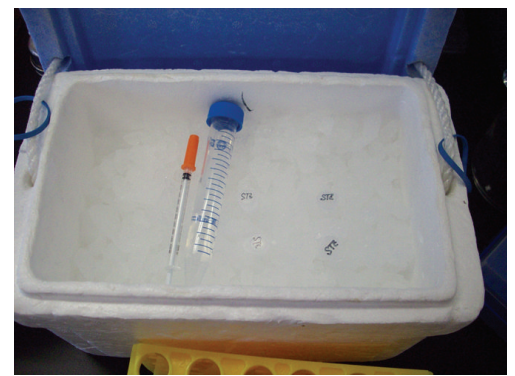

(a)

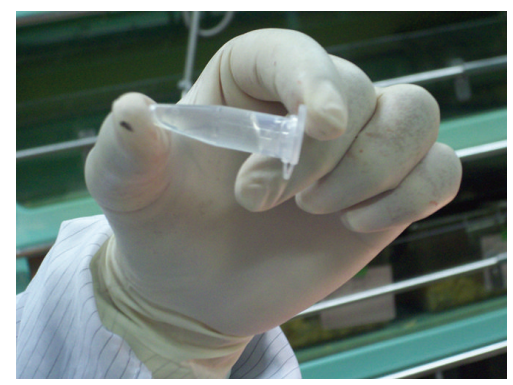

(d)

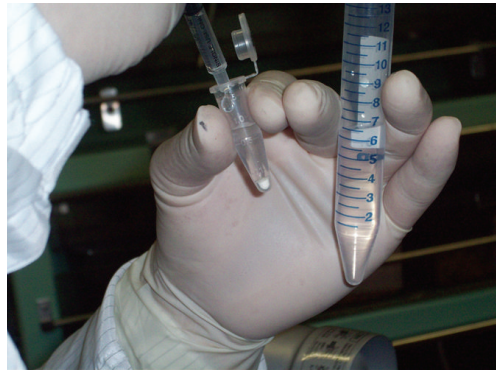

(b)

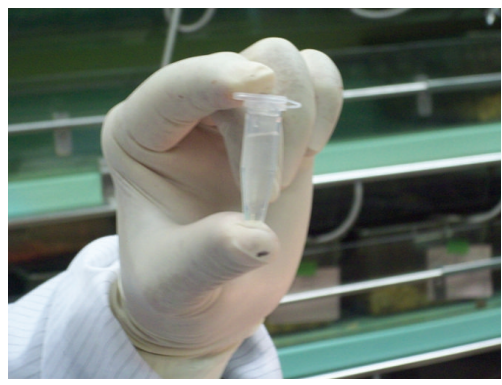

(e)

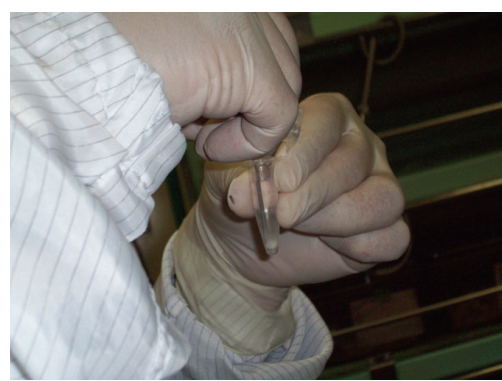

(c)

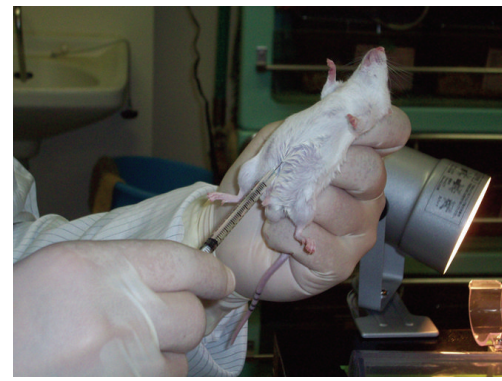

(f)

FIgURE 1: STZ injection via intraperitoneum. (a) Preparation. $1.5 \mathrm{~mL}$ centrifuge tube with STZ, 29-gauge needle, $1 \mathrm{~mL}$ syringe, ice box with crushed ice, citrate buffer solution, and an 18-gauge needle are used. (b)-(e) Dissolving STZ. (b) Citrate buffer solution is poured into STZ. (c) Crushing the larger clusters of STZ with an 18-gauge needle. (d) and (e) Dissolving by shaking gently. (f) STZ solution is injected via the lower abdomen with care not to injure organs.

transplantation and for understanding the mechanism of $\mathrm{DM}$, including islet regeneration.

\subsection{Spontaneous Type 1 Diabetic Models for Islet Transplanta-} tion. Spontaneous type 1 diabetic animals are useful models to understand the mechanism of type $1 \mathrm{DM}$ because this model has autoimmunity, which causes islet injury like that found in type $1 \mathrm{DM}$ patients. In general, it is difficult to study this disease in human and also difficult to analyze the findings in patients who received islet transplantation because of ethical considerations [123]. This is also a reliable model for analyzing the induction of transplantation tolerance [124] and the special problems of tolerance induction by autoimmunity [125]. The represented spontaneous diabetic models are BB rat and NOD mouse.

The mechanism of inducing DM in NOD mice is insulitis, which is inducted at 4 to 5 weeks after birth, and results in approximately $90 \%$ of females and $60 \%$ of males developing DM when they are 7 months old [123]. The autoimmunity of NOD mice is characterized by many abnormalities in the immune system including defects in regulatory $\mathrm{T}$ cells, which also appears in human in type 1 DM [123]. Regulatory $\mathrm{T}$ cells have a role of maintaining immune tolerance. Thus, it is considered that a defect in regulatory $\mathrm{T}$ cells causes them to be resistant to tolerance in islet transplantation [126]. As a model of type $1 \mathrm{DM}$, NOD mice have been used for the assessments of many immunosuppressants.
The first successful regime of immunosuppressants for islet transplantation was a combination of an antiinterleukin (IL)-2 monoclonal antibody daclizumab for the induction, the calcineurin inhibitor tacrolimus, and the mammalian target of rapamycin (mTOR) inhibitor sirolimus for the maintenance referred to as the Edmonton protocol in 2000 [4]. The utility of the regime was proved by the Miami group with an animal study using NOD mice [127]. This group performed islet allotransplantation using diabetic NOD mice and confirmed that a combination of tacrolimus and sirolimus could prolong the graft survival (over 100 days in $28.6 \%$ of recipient mice) and a combination of the three agents could achieve even better graft survival (over 100 days in $75 \%$ ). The Minnesota group examined the effectiveness of antithymocyte globulin (ATG) and the antitumor necrosis factor (TNF)- $\alpha$ receptor inhibitor etanercept for the induction as a novel regime for single donor transplantation and achieved $62.5 \%$ insulin-free in 1 year after transplantation [128]. Recently, they assessed a novel immunosuppressant regime using FcR nonbinding anti-CD3 antibody or T celldepleting antibodies and a TNF- $\alpha$ inhibitor by comparing the recipients enrolled in the Collaborative Islet Transplant Registry and revealed that the combination could result in an insulin-free rate of 5 years (approximately 50\%) [129]. These novel immunosuppressants were also evaluated using NOD mice by many groups. Vergani and colleagues compared between treatment of ATG and cytotoxic T-lymphocyte antigen 4 and antibodies (CTLA4-Ig) and no immunosuppressants in the transplantation of $\mathrm{BALB} / \mathrm{c}$ mice islets to 


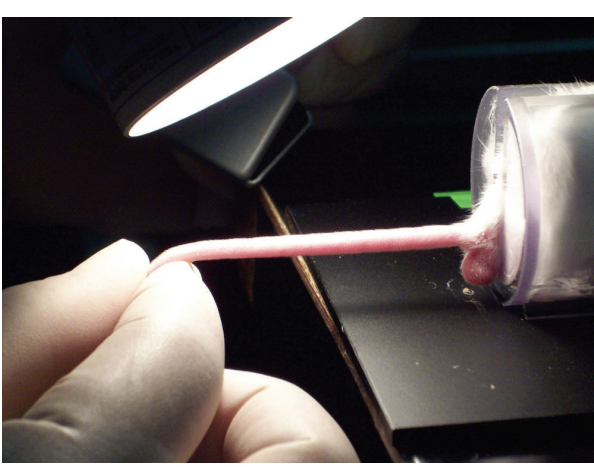

(a)

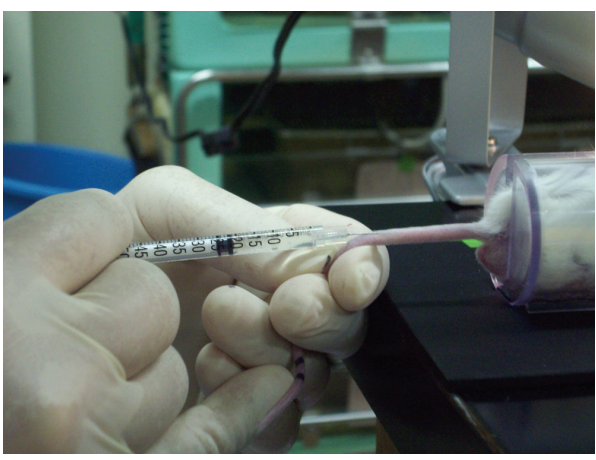

(b)

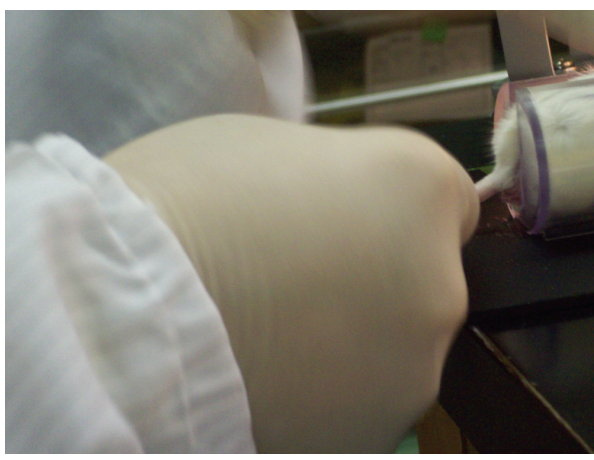

(c)

FIgURe 2: STZ intravenous injection. (a) Dilating tail vein by warming (using light in this case). (b) Injecting solution via the tail vein. A 29-gauge needle is inserted at the upper $1 / 2 \sim 1 / 3$ of the tail. STZ solution is injected slowly. (c) After finishing injection, the needle is removed while pressing a part of puncture with the thumb to prevent leakage of the STZ solution.

NOD mice and revealed prolonged graft survival [130]. AntiCD 3 monoclonal antibody has been shown to be effective in suppressing autoimmunity. Baeke and colleagues revealed that a combination of anti-CD3 monoclonal antibody, ciclosporin A, and vitamin D prolonged the graft survival in islet allotransplanted diabetic NOD mice by reducing CD4+ T cells and increasing FOXP3+CD4+ regulatory T cells [131]. Additionally, Mamchak and colleagues proved that antiCD3 monoclonal antibody treatment with oral insulin intake improved the blood glucose level of diabetic NOD mice by

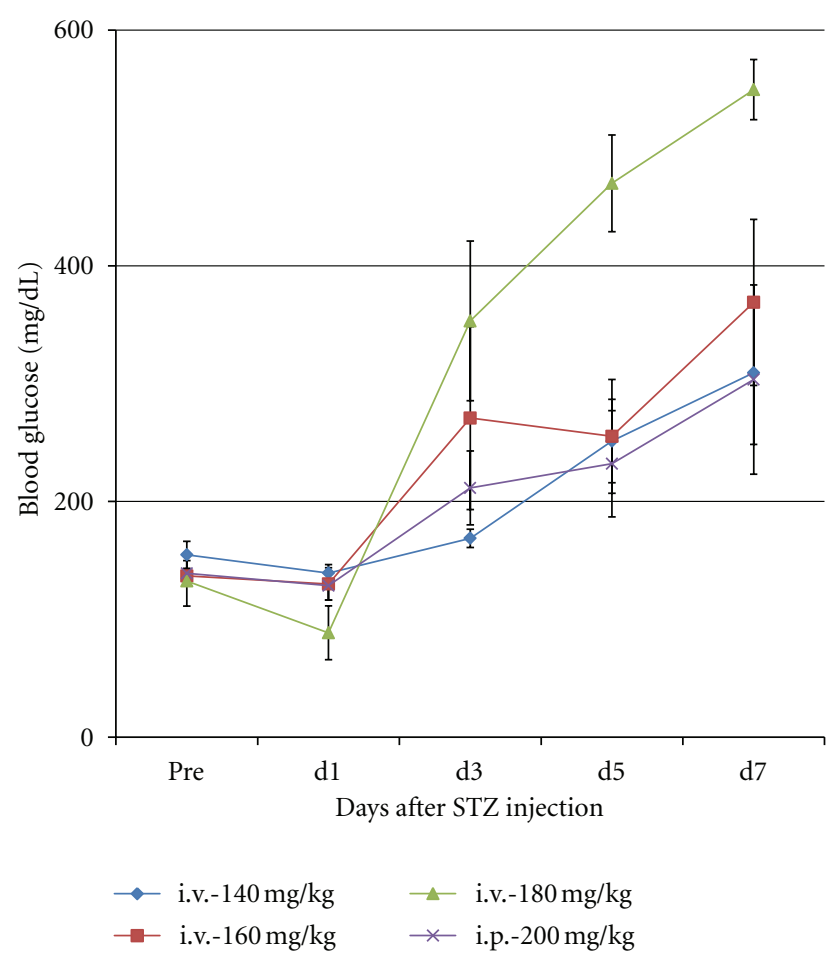

Figure 3: Blood glucose levels after STZ injection in BALB/c mice. The effect of $160 \mathrm{mg} / \mathrm{kg}$ of STZ injection via i.v. was equally to that of $200 \mathrm{mg} / \mathrm{kg}$ of STZ injection via i.p. in blood glucose level.

increasing regulatory $\mathrm{T}$ cells and decreasing $\mathrm{CD} 4+\mathrm{CD} 25+\mathrm{T}$ cells, indicating a suppression of autoimmunity [132].

To succeed in clinical islet transplantation, it is necessary to control both allo- and autoimmunity. NOD mice are suitable for evaluating the influences of both types of immunity in islet transplantation.

\section{Conclusion}

In summary, many diabetic animal models have been used for assessing the effects of therapeutic interventions on the outcome of islet transplantation. All the animals that we mentioned were models with a deficiency in islet function, but the mechanisms by which they induce DM are significantly different, and, thus, it is important to select the model according to the aim of the study.

\section{Conflict of Interests}

Conflict of interests does not exist in any companies.

\section{Acknowledgment}

The authors thank Professor Masafumi Goto and his collaborators for technical support in inducing DM with intravenous injection of STZ. This study is supported by Grant-in-Aid for Scientific Research from the Ministry of Education, Culture, Sports Science and Technology of Japan (B: 22390253 S. Egawa), Challenging Exploratory Research: 
24659582 and C: 22591513 (N. Sakata), the Takeda Science Foundation, the Gonryo Medical Foundation, the Suzuken Memorial Foundation (N. Sakata), and Network Medicine Global-COE Program from the Ministry of Education, Culture, Sports Science and Technology of Japan (M. Unno).

\section{References}

[1] P. E. Lacy and M. Kostianovsky, "Method for the isolation of intact islets of Langerhans from the rat pancreas," Diabetes, vol. 16, no. 1, pp. 35-39, 1967.

[2] C. B. Kemp, M. J. Knight, D. W. Scharp, P. E. Lacy, and W. F. Ballinger, "Transplantation of isolated pancreatic islets into the portal vein of diabetic rats," Nature, vol. 244, no. 5416, p. 447, 1973.

[3] A. G. Tzakis, C. Ricordi, R. Alejandro et al., "Pancreatic islet transplantation after upper abdominal exenteration and liver replacement," The Lancet, vol. 336, no. 8712, pp. 402-405, 1990.

[4] A. M. J. Shapiro, J. R. T. Lakey, E. A. Ryan et al., "Islet transplantation in seven patients with type 1 diabetes mellitus using a glucocorticoid-free immunosuppressive regimen," The New England Journal of Medicine, vol. 343, no. 4, pp. 230238, 2000.

[5] M. McCall and A. M. James Shapiro, "Update on islet transplantation," Cold Spring Harbor Perspectives in Medicine, no. 2, Article ID a007823, 2012.

[6] M. H. B. Brendel, A. Schulz, and R. Bretzel, International Islet Tranplant Registry Report, University of Giessen, Giessen, Germany, 1999.

[7] D. A. Rees and J. C. Alcolado, "Animal models of diabetes mellitus," Diabetic Medicine, vol. 22, no. 4, pp. 359-370, 2005.

[8] F. L. J. Wöhler, "Untersuchungen über die Natur der Harnsäure," Annales Pharmaceutiques, vol. 26, pp. 241-340, 1838 (German).

[9] J. S. Dunn and N. G. B. Mcletchie, "Experimental alloxan diabetes in the rat," The Lancet, vol. 242, no. 6265, pp. 384387, 1943 .

[10] J. S. S. H. Dunn and N. G. B. McLetchie, "Necrosis of islets of Langerhans produced experimentally," The Lancet, vol. 244, pp. 484-487, 1943.

[11] N. Rakieten, M. L. Rakieten, and M. V. Nadkarni, "Studies on the diabetogenic action of streptozotocin (NSC-37917)," Cancer Chemotherapy Reports, vol. 29, pp. 91-98, 1963.

[12] S. Lenzen, "The mechanisms of alloxan- and streptozotocininduced diabetes," Diabetologia, vol. 51, no. 2, pp. 216-226, 2008.

[13] S. Makino, K. Kunimoto, and Y. Muraoka, "Breeding of a non-obese, diabetic strain of mice," Experimental Animals, vol. 29, no. 1, pp. 1-13, 1980.

[14] A. F. Nakhooda, A. A. Like, C. I. Chappel, F. T. Murray, and E. B. Marliss, "The spontaneously diabetic Wistar rat. Metabolic and morphologic studies," Diabetes, vol. 26, no. 2, pp. 100$112,1977$.

[15] A. J. Bone, P. R. Hitchcock, D. J. Gwilliam, J. M. Cunningham, and J. Barley, "Insulitis and mechanisms of disease resistance: studies in an animal model of insulin dependent diabetes mellitus," Journal of Molecular Medicine, vol. 77, no. 1, pp. 57-61, 1999.

[16] J. W. Yoon, H. S. Jun, and P. Santamaria, "Cellular and molecular mechanisms for the initiation and progression of $\beta$ cell destruction resulting from the collaboration between macrophages and T cells," Autoimmunity, vol. 27, no. 2, pp. 109-122, 1998.
[17] A. Rabinovitch, W. Suarez-Pinzon, A. El-Sheikh, O. Sorensen, and R. F. Power, "Cytokine gene expression in pancreatic islet-infiltrating leukocytes of $\mathrm{BB}$ rats: expression of Th1 cytokines correlates with $\beta$-cell destructive insulitis and IDDM," Diabetes, vol. 45, no. 6, pp. 749-754, 1996.

[18] M. Lohr, H. Markholst, T. Dyrberg, G. Kloppel, M. Oberholzer, and A. Lernmark, "Insulitis and diabetes are preceded by a decrease in $\beta$ cell volume in diabetes-prone BB rats," Pancreas, vol. 4, no. 1, pp. 95-100, 1989.

[19] F. J. Lally, H. Ratcliff, and A. J. Bone, "Apoptosis and disease progression in the spontaneously diabetic BB/S rat," Diabetologia, vol. 44, no. 3, pp. 320-324, 2001.

[20] A. M. Ingalls, M. M. Dickie, and G. D. Snell, "Obese, a new mutation in the house mouse," The Journal of Heredity, vol. 41, no. 12, pp. 317-318, 1950.

[21] L. Boquist, B. Hellman, A. Lernmark, and I. B. Taljedal, "Influence of the mutation "diabetes" on insulin release and islet morphology in mice of different genetic backgrounds," Journal of Cell Biology, vol. 62, no. 1, pp. 77-89, 1974.

[22] T. W. Kurtz, R. C. Morris, and H. A. Pershadsingh, "The Zucker fatty rat as a genetic model of obesity and hypertension," Hypertension, vol. 13, no. 6, pp. 896-901, 1989.

[23] Y. Goto, M. Kakizaki, and N. Masaki, "Production of spontaneous diabetic rats by repetition of selective breeding," Tohoku Journal of Experimental Medicine, vol. 119, no. 1, pp. 85-90, 1976.

[24] K. Kawano, T. Hirashima, S. Mori, Y. Saitoh, M. Kurosumi, and T. Natori, "Spontaneous long-term hyperglycemic rat with diabetic complications: Otsuka Long-Evans Tokushima Fatty (OLETF) strain,” Diabetes, vol. 41, no. 11, pp. 14221428, 1992.

[25] Y. Zhang, R. Proenca, M. Maffei, M. Barone, L. Leopold, and J. M. Friedman, "Positional cloning of the mouse obese gene and its human homologue," Nature, vol. 372, no. 6505, pp. 425-432, 1994.

[26] G. H. Lee, R. Proenca, J. M. Montez et al., "Abnormal splicing of the leptin receptor in diabetic mice," Nature, vol. 379, no. 6566, pp. 632-635, 1996.

[27] M. S. Phillips, Q. Liu, H. A. Hammond et al., "Leptin receptor missense mutation in the fatty Zucker rat," Nature Genetics, vol. 13, no. 1, pp. 18-19, 1996.

[28] R. L. Joshi, B. Lamothe, N. Cordonnier et al., "Targeted disruption of the insulin receptor gene in the mouse results in neonatal lethality," EMBO Journal, vol. 15, no. 7, pp. 15421547, 1996.

[29] H. Tamemoto, T. Kadowaki, K. Tobe et al., "Insulin resistance and growth retardation in mice lacking insulin receptor substrate-1," Nature, vol. 372, no. 6502, pp. 182-186, 1994.

[30] D. J. Withers, J. S. Gutierrez, H. Towery et al., "Disruption of IRS-2 causes type 2 diabetes in mice," Nature, vol. 391, no. 6670, pp. 900-904, 1998.

[31] N. Kubota, K. Tobe, Y. Terauchi et al., "Disruption of insulin receptor substrate 2 causes type 2 diabetes because of liver insulin resistance and lack of compensatory $\beta$-cell hyperplasia," Diabetes, vol. 49, no. 11, pp. 1880-1889, 2000.

[32] T. Szkudelski, "The mechanism of alloxan and streptozotocin action in B cells of the rat pancreas," Physiological Research, vol. 50, no. 6, pp. 537-546, 2001.

[33] Z. Wang and H. Gleichmann, "GLUT2 in pancreatic islets: crucial target molecule in diabetes induced with multiple low doses of streptozotocin in mice," Diabetes, vol. 47, no. 1, pp. 50-56, 1998.

[34] W. J. Schnedl, S. Ferber, J. H. Johnson, and C. B. Newgard, "STZ transport and cytotoxicity: specific enhancement in 
GLUT2-expressing cells," Diabetes, vol. 43, no. 11, pp. 13261333, 1994.

[35] W. F. Ballinger and P. E. Lacy, "Transplantation of intact pancreatic islets in rats," Surgery, vol. 72, no. 2, pp. 175-186, 1972.

[36] W. F. Ballinger, P. E. Lacy, D. W. Scharp, C. B. Kemp, and M. Knight, "Isografts and allografts of pancreatic islets in rats," British Journal of Surgery, vol. 60, no. 4, p. 313, 1973.

[37] R. C. Kramp, C. C. Congdon, and L. H. Smith, "Isogeneic or allogeneic transplantation of duct ligated pancreas in streptozotocin diabetic mice," European Journal of Clinical Investigation, vol. 5, no. 3, pp. 249-258, 1975.

[38] D. W. Scharp, J. J. Murphy, W. T. Newton, W. F. Ballinger, and P. E. Lacy, "Transplantation of islets of Langerhans in diabetic rhesus monkeys," Surgery, vol. 77, no. 1, pp. 100-105, 1975.

[39] A. J. Matas, D. E. R. Sutherland, M. W. Steffes, and J. S. Najarian, "Short term culture of adult pancreatic fragments for purification and transplantation of islets of Langerhans," Surgery, vol. 80, no. 2, pp. 183-191, 1976.

[40] A. Tahara, E. Kurosaki, M. Yokono et al., "Antidiabetic effects of SGLT2-selective inhibitor Ipragliflozin in streptozotocinnicotinamide-induced mildly diabetic mice," Journal of Pharmacological Sciences, vol. 120, pp. 36-44, 2012.

[41] C. Liu, B. Koeberlein, M. D. Feldman et al., "Accumulation of intrahepatic islet amyloid in a nonhuman primate transplant model," Endocrinology, vol. 153, pp. 1673-1683, 2012.

[42] B. Yang, M. Li, Z. G. Shi, and Q. Z. Feng, "Bosentan ameliorates the expression of fibrotic related growth factors and collagen-1 in diabetic mice," Anadolu Kardiyoloji Dergisi, vol. 12, no. 8, pp. 621-627, 2012.

[43] H. K. Kim, "Ecklonia cava inhibits glucose absorption and stimulates insulin secretion in streptozotocin-induced diabetic mice," Evidence-Based Complementary and Alternative Medicine, vol. 2012, Article ID 439294, 7 pages, 2012.

[44] Y. Zhang, R. N. Bone, W. Cui et al., "Regeneration of pancreatic non-beta endocrine cells in adult mice following a single diabetes-inducing dose of streptozotocin," PLoS One, vol. 7, Article ID e36675, 2012.

[45] M. J. Kim and H. K. Kim, "Insulinotrophic and hypolipidemic effects of Ecklonia cava in streptozotocin-induced diabetic mice," Asian Pacific Journal of Tropical Medicine, vol. 5, pp. 374-379, 2012.

[46] C. D. Wang, B. S. Teng, Y. M. He et al., "Effect of a novel proteoglycan PTP1B inhibitor from Ganoderma lucidum on the amelioration of hyperglycaemia and dyslipidaemia in $\mathrm{db} / \mathrm{db}$ mice," British Journal of Nutrition, vol. 108, pp. 20142025, 2012.

[47] T. Wang, F. Fu, B. Han, L. Zhang, and X. Zhang, "Danshensu ameliorates the cognitive decline in streptozotocininduced diabetic mice by attenuating advanced glycation end product-mediated neuroinflammation," Journal of Neuroimmunology, vol. 245, pp. 79-86, 2012.

[48] A. Matsuyama-Yokono, A. Tahara, R. Nakano et al., "ASP8497 is a novel selective and competitive dipeptidyl peptidase-IV inhibitor with antihyperglycemic activity," Biochemical Pharmacology, vol. 76, no. 1, pp. 98-107, 2008.

[49] Y. Liu, Y. Qu, R. Wang et al., "The alternative crosstalk between RAGE and nitrative thioredoxin inactivation during diabetic myocardial ischemia-reperfusion injury," American Journal of Physiology, vol. 303, pp. E841-E852, 2012.

[50] L. Tie, Y. An, J. Han et al., "Genistein accelerates refractory wound healing by suppressing superoxide and FoxO1/iNOS pathway in type 1 diabetes," The Journal of Nutritional Biochemistry, vol. 24, pp. 88-96, 2013.
[51] I. Loeffler, M. Liebisch, and G. Wolf, "Collagen VIII influences epithelial phenotypic changes in experimental diabetic nephropathy," American Journal of Physiology, vol. 303, pp. F733-F745, 2012.

[52] H. Y. Ou, H. T. Wu, H. C. Hung, Y. C. Yang, J. S. Wu, and C. J. Chang, "Endoplasmic reticulum stress induces the expression of fetuin-A to develop insulin resistance," Endocrinology, vol. 153, pp. 2974-2984, 2012.

[53] L. Tie, H. Q. Yang, Y. An et al., “Ganoderma lucidum polysaccharide accelerates refractory wound healing by inhibition of mitochondrial oxidative stress in type 1 diabetes," Cellular Physiology and Biochemistry, vol. 29, pp. 583-594, 2012.

[54] W. Zhu, W. Li, and R. L. Silverstein, "Advanced glycation end products induce a prothrombotic phenotype in mice via interaction with platelet CD36," Blood, vol. 119, pp. 61366144, 2012.

[55] Y. Z. Cheng, L. J. Chen, W. J. Lee, M. F. Chen, H. Jung Lin, and J. T. Cheng, "Increase of myocardial performance by Rhodiola-ethanol extract in diabetic rats," Journal of Ethnopharmacology, vol. 144, pp. 234-239, 2012.

[56] X. Zhong, L. Wang, Y. Wang et al., "Exogenous hydrogen sulfide attenuates diabetic myocardial injury through cardiac mitochondrial protection," Molecular and Cellular Biochemistry, vol. 371, no. 1-2, pp. 187-198, 2012.

[57] M. F. Cheng, L. J. Chen, and J. T. Cheng, "Decrease of Klotho in the kidney of streptozotocin-induced diabetic rats," Journal of Biomedicine and Biotechnology, vol. 2010, Article ID 513853, 7 pages, 2010.

[58] A. R. Ochman, C. A. Lipinski, J. A. Handler, A. G. Reaume, and M. S. Saporito, "The Lyn kinase activator MLR-1023 is a novel insulin receptor potentiator that elicits a rapidonset and durable improvement in glucose homeostasis in animal models of type 2 diabetes," Journal of Pharmacology and Experimental Therapeutics, vol. 342, pp. 23-32, 2012.

[59] Y. Lee, E. D. Berglund, M. Y. Wang et al., "Metabolic manifestations of insulin deficiency do not occur without glucagon action," Proceedings of the National Academy of Sciences of the United States of America, vol. 109, pp. 1497214976, 2012.

[60] N. Blaes, C. Pecher, M. Mehrenberger et al., "Bradykinin inhibits high glucose- and growth factor-induced collagen synthesis in mesangial cells through the B2-kinin receptor," American Journal of Physiology, vol. 303, pp. F293-F303, 2012.

[61] A. Ulugol, C. Oltulu, O. Gunduz et al., "5-HT7 receptor activation attenuates thermal hyperalgesia in streptozocininduced diabetic mice," Pharmacology Biochemistry and Behavior, vol. 102, pp. 344-348, 2012.

[62] Y. Y. Li, H. H. Liu, H. L. Chen, and Y. P. Li, "Adiposederived mesenchymal stem cells ameliorate STZ-induced pancreas damage in type 1 diabetes," Bio-Medical Materials and Engineering, vol. 22, pp. 97-103, 2012.

[63] A. K. Verma, H. Singh, M. Satyanarayana et al., "Flavonebased novel antidiabetic and antidyslipidemic agents," Journal of Medicinal Chemistry, vol. 55, pp. 4551-4567, 2012.

[64] N. Tirgan, G. A. Kulp, P. Gupta et al., "Nicotine exposure exacerbates development of cataracts in a type 1 diabetic rat model," Experimental Diabetes Research, vol. 2012, Article ID 349320, 7 pages, 2012.

[65] S. Talbot, H. De Brito Gariepy, J. Saint-Denis, and R. Couture, "Activation of kinin B1 receptor evokes hyperthermia through a vagal sensory mechanism in the rat," Journal of Neuroinflammation, vol. 9, article 214, 2012. 
[66] L. Pihl, P. Persson, A. Fasching, P. Hansell, G. F. DiBona, and F. Palm, "Insulin induces the correlation between renal blood flow and glomerular filtration rate in diabetes: implications for mechanisms causing hyperfiltration," American Journal of Physiology, vol. 303, pp. 39-47, 2012.

[67] R. Zhang, D. Thor, X. Han, L. Anderson, and R. Rahimian, "Sex differences in mesenteric endothelial function of streptozotocin-induced diabetic rats: a shift in the relative importance of EDRFs," American Journal of Physiology, vol. 303, no. 10, pp. 1183-1198, 2012.

[68] S. Delli Pizzi, R. Madonna, M. Caulo, G. L. Romani, R. De Caterina, and A. Tartaro, "MR angiography, MR imaging and proton MR spectroscopy in-vivo assessment of skeletal muscle ischemia in Diabetic rats," PLoS One, vol. 7, Article ID e44752, 2012.

[69] G. B. Peres, M. A. Juliano, M. J. Simoes, and Y. M. Michelacci, "Lysosomal enzymes are decreased in the kidney of diabetic rats," Biochimica et Biophysica Acta, vol. 1832, pp. 85-95, 2013.

[70] R. Premalatha, R. Jubendradass, S. J. Rani, K. Srikumar, and P. P. Mathur, "A phytooxysterol, 28-homobrassinolide modulates rat testicular steroidogenesis in normal and Diabetic rats," Reproductive Sciences. In press.

[71] F. Khaliq, A. Parveen, S. Singh, M. E. Hussain, and M. Fahim, "Terminalia arjuna improves cardiovascular autonomic neuropathy in streptozotocin-induced Diabetic rats," Cardiovascular Toxicology. In press.

[72] W. Liu, Y. Zhang, S. Liu et al., "The expression of intermediate filament protein nestin and its association with cyclindependentkinase 5 in the glomeruli of rats with diabetic nephropathy," The American Journal of the Medical Sciences. In press.

[73] E. Salum, P. Kampus, M. Zilmer et al., "Effect of vitamin D on aortic remodeling in streptozotocin-induced diabetes," Cardiovascular Diabetology, vol. 11, article 58, 2012.

[74] Y. Yoshikumi, H. Ohno, J. Suzuki et al., "Up-regulation of JAM-1 in AR42J cells treated with activin A and betacellulin and the diabetic regenerating islets," Endocrine Journal, vol. 55, no. 4, pp. 757-765, 2008.

[75] J. Arambasic, M. Mihailovic, A. Uskokovic et al., "Alphalipoic acid upregulates antioxidant enzyme gene expression and enzymatic activity in diabetic rat kidneys through an O-GlcNAc-dependent mechanism," European Journal of Nutrition. In press.

[76] K. M. Alkharfy, "Influence of overt diabetes mellitus on cyclosporine pharmacokinetics in a canine model," Experimental Diabetes Research, vol. 2009, Article ID 363787, 6 pages, 2009.

[77] S. Matsuo, S. Hayashi, T. Watanabe et al., "Emphysematous cystitis in a chemically-induced diabetic dog," Journal of Toxicologic Pathology, vol. 22, no. 4, pp. 289-292, 2009.

[78] S. Zhu, Y. Lu, J. Zhu et al., "Effects of intrahepatic bonederived mesenchymal stem cells autotransplantation on the diabetic Beagle dogs," Journal of Surgical Research, vol. 168, no. 2, pp. 213-223, 2011.

[79] K. Kavanagh, D. M. Flynn, C. Nelson, L. Zhang, and J. D. Wagner, "Characterization and validation of a streptozotocin-induced diabetes model in the vervet monkey," Journal of Pharmacological and Toxicological Methods, vol. 63, no. 3, pp. 296-303, 2011.

[80] Y. Saisho, E. Manesso, A. E. Butler et al., "Ongoing $\beta$ cell turnover in adult nonhuman primates is not adaptively increased in streptozotocin-induced diabetes," Diabetes, vol. 60, no. 3, pp. 848-856, 2011.
[81] C. Zou, S. Wang, F. Huang, and Y. A. Zhang, "Advanced glycation end products and ultrastructural changes in corneas of long-term streptozotocin-induced diabetic monkeys," Cornea, vol. 31, pp. 1455-1459, 2012.

[82] C. Zou, J. Wang, S. Wang et al., "Characterizing the induction of diabetes in juvenile cynomolgus monkeys with different doses of streptozotocin," Science China Life Sciences, vol. 55, pp. 210-218, 2012.

[83] A. Sheehy, S. Hsu, A. Bouchard et al., "Comparative vascular responses three months after paclitaxel and everolimuseluting stent implantation in streptozotocin-induced diabetic porcine coronary arteries," Cardiovascular Diabetology, vol. 11, article 75, 2012.

[84] J. K. Juranek, A. Aleshin, E. M. Rattigan et al., "Morphological changes and immunohistochemical expression of RAGE and its ligands in the sciatic nerve of hyperglycemic pig (sus scrofa)," Biochemistry Insights, vol. 2010, pp. 47-59, 2010.

[85] R. W. Jamieson, M. Zilvetti, D. Roy et al., "Hepatic steatosis and normothermic perfusion-preliminary experiments in a porcine model," Transplantation, vol. 92, no. 3, pp. 289-295, 2011.

[86] S. J. Koopmans, J. Vandermeulen, J. Wijdenes, H. Corbijn, and R. Dekker, "The existence of an insulin-stimulated glucose and non-essential but not essential amino acid substrate interaction in diabetic pigs," BMC Biochemistry, vol. 12, no. 1, article 25, 2011.

[87] C. von Wilmowsky, P. Stockmann, I. Harsch et al., "Diabetes mellitus negatively affects peri-implant bone formation in the diabetic domestic pig," Journal of Clinical Periodontology, vol. 38, no. 8, pp. 771-779, 2011.

[88] A. Banga, E. Akinci, L. V. Greder, J. R. Dutton, and J. M. Slack, "In vivo reprogramming of Sox9+ cells in the liver to insulin-secreting ducts," Proceedings of the National Academy of Sciences of the United States of America, vol. 109, pp. 1533615341, 2012.

[89] B. Bose, P. S. Shenoy, S. Konda, and P. Wangikar, "Human embryonic stem cell differentiation into insulin secreting beta-cells for diabetes," Cell Biology International, vol. 36, pp. 1013-1020, 2012.

[90] J. Han, B. McLane, E. H. Kim, J. W. Yoon, and H. S. Jun, "Remission of diabetes by insulin gene therapy using a hepatocyte-specific and glucose-responsive synthetic promoter," Molecular Therapy, vol. 19, no. 3, pp. 470-478, 2011.

[91] J. Ventura-Sobrevilla, V. D. Boone-Villa, C. N. Aguilar et al., "Effect of varying dose and administration of streptozotocin on blood sugar in male CD1 mice," Proceedings of the Western Pharmacology Society, vol. 54, pp. 5-9, 2011.

[92] D. A. Axler, "Stability of the diabetogenic activity of streptozotocin," IRCS Medical Science, vol. 10, no. 2, pp. 157-158, 1982.

[93] E. W. Lampe, D. E. Sutherland, and H. S. Najariam, "Autotransplantation of porcine islets of langerhans Langerhans," Surgery, vol. 79, no. 2, pp. 138-143, 1976.

[94] E. Kolb, R. Ruckert, and F. Largiader, "Intraportal and intrasplenic autotransplantation of pancreatic islets in the dog," European Surgical Research, vol. 9, no. 6, pp. 419-426, 1977.

[95] G. J. Kretschmer, D. E. R. Sutherland, A. J. Matas, T. L. Cain, and J. S. Najarian, "Autotransplantation of pancreatic islets without separation of exocrine and endocrine tissue in totally pancreatectomized dogs," Surgery, vol. 82, no. 1, pp. 74-81, 1977.

[96] G. J. Kretschmer, D. E. R. Sutherland, A. J. Matas, M. W. Steffes, and J. S. Najarian, "The dispersed pancreas: 
transplantation without islet purification in totally pancreatectomized dogs," Diabetologia, vol. 13, no. 5, pp. 495-502, 1977.

[97] J. S. Najarian, D. E. R. Sutherland, D. Baumgartner et al., "Total or near total pancreatectomy and islet autotransplantation for treatment of chronic pancreatitis," Annals of Surgery, vol. 192, no. 4, pp. 526-542, 1980.

[98] D. Alderson, T. N. Walsh, and J. R. Farndon, "Islet cell transplantation in diabetic dogs: studies of graft function and storage," British Journal of Surgery, vol. 71, no. 10, pp. 756760, 1984.

[99] N. M. Kneteman, R. V. Rajotte, and G. L. Warnock, "Longterm normoglycemia in pancreatectomized dogs transplanted with frozen/thawed pancreatic islets," Cryobiology, vol. 23, no. 3, pp. 214-221, 1986.

[100] T. N. Walsh, J. M. Fitzpatrick, D. Alderson, K. G. M. M. Alberti, and J. R. Farndon, "Diurnal insulin and glucose profiles following transplantation of fresh and cryopreserved canine pancreatic islets," British Journal of Surgery, vol. 76, no. 12, pp. 1287-1290, 1989.

[101] M. G. Evans, G. L. Warnock, N. M. Kneteman, and R. V. Rajotte, "Reversal of diabetes in dogs by transplantation of pure cryopreserved islets," Transplantation, vol. 50, no. 2, pp. 202-206, 1990.

[102] M. M. Levy, R. J. Ketchum, J. E. Tomaszewski, A. Naji, C. F. Barker, and K. L. Brayman, "Intrathymic islet transplantation in the canine: I. Histological and functional evidence of autologous intrathymic islet engraftment and survival in pancreatectomized recipients," Transplantation, vol. 73, no. 6, pp. 842-852, 2002.

[103] G. Christoffersson, J. Henriksnäs, L. Johansson et al., "Clinical and experimental pancreatic islet transplantation to striated muscle: establishment of a vascular system similar to that in native islets," Diabetes, vol. 59, no. 10, pp. 2569-2578, 2010.

[104] M. L. C. Madureira, "Adult pancreatic tissue fate after pancreatic fragment autotransplantation into the spleen of the pancreatectomized dog," World Journal of Surgery, vol. 18, no. 2, pp. 259-265, 1994.

[105] Z. Ao, K. Matayoshi, J. R. T. Lakey, R. V. Rajotte, and G. L. Warnock, "Survival and function of purified islets in the omental pouch site of outbred dogs," Transplantation, vol. 56, no. 3, pp. 524-529, 1993.

[106] K. Motojima, N. Kohara, J. Maeda, M. Yamaguchi, and T. Kanematsu, "A comparison of endocrine and exocrine function after pancreatic fragment autotransplantation into splenic pulp, portal vein, and hepatic parenchyma," Transplantation, vol. 53, no. 3, pp. 527-532, 1992.

[107] A. Rajab, J. Buss, E. Diakoff, G. A. Hadley, K. Osei, and R. M. Ferguson, "Comparison of the portal vein and kidney subcapsule as sites for primate islet autotransplantation," Cell Transplantation, vol. 17, no. 9, pp. 1015-1023, 2008.

[108] N. M. Kneteman, D. Alderson, and D. W. Scharp, "Longterm normoglycemia in pancreatectomized dogs following pancreatic islet allotransplantation and cyclosporine immunosuppression," Transplantation, vol. 44, no. 5, pp. 595-599, 1987.

[109] I. Koyama, M. Williams, J. L. Cameron, and G. D. Zuidema, "Experimental pancreatic allotransplantation in large animals. The role of donor kidney and cyclosporine in modifying rejection," Transplantation, vol. 42, no. 4, pp. 333-336, 1986.
[110] R. Alejandro, R. Cutfield, F. L. Shienvold, Z. Latif, and D. H. Mintz, "Successful long-term survival of pancreatic islet allografts in spontaneous or pancreatectomy-induced diabetes in dogs. Cyclosporine-induced immune unresponsiveness," Diabetes, vol. 34, no. 8, pp. 825-828, 1985.

[111] N. Kumagai, J. C. LaMattina, C. Kamano et al., "Vascularized islet cell transplantation in miniature swine: islet-kidney allografts correct the diabetic hyperglycemia induced by total pancreatectomy," Diabetes, vol. 51, no. 11, pp. 3220-3228, 2002.

[112] T. Kin, H. Iwata, Y. Aomatsu et al., "Xenotransplantation of pig islets in diabetic dogs with use of a microcapsule composed of agarose and polystyrene sulfonic acid mixed gel," Pancreas, vol. 25, no. 1, pp. 94-100, 2002.

[113] H. Tashiro, H. Iwata, G. L. Warnock et al., "Characterization and transplantation of agarose microencapsulated canine islets of Langerhans," Annals of Transplantation, vol. 2, no. 3, pp. 33-39, 1997.

[114] T. Maki, I. Otsu, J. J. O’Neil et al., “Treatment of diabetes by xenogeneic islets without immunosuppression: use of a vascularized bioartificial pancreas," Diabetes, vol. 45, no. 3, pp. 342-347, 1996.

[115] R. P. Lanza, K. M. Borland, P. Lodge et al., "Treatment of severely diabetic pancreatectomized dogs using a diffusionbased hybrid pancreas," Diabetes, vol. 41, no. 7, pp. 886-889, 1992.

[116] A. P. Monaco, T. Maki, H. Ozato et al., "Transplantation of islet allografts and xenografts in totally pancreatectomized diabetic dogs using the Hybrid Artificial Pancreas," Annals of Surgery, vol. 214, no. 3, pp. 339-362, 1991.

[117] T. Wang, J. Adcock, W. Kühtreiber et al., "Successful allotransplantation of encapsulated islets in pancreatectomized canines for diabetic management without the use of immunosuppression," Transplantation, vol. 85, no. 3, pp. 331-337, 2008.

[118] S. F. Grundfest-Broniatowski, G. Tellioglu, K. S. Rosenthal et al., "A new bioartificial pancreas utilizing amphiphilic membranes for the immunoisolation of porcine islets a pilot study in the canine," ASAIO Journal, vol. 55, no. 4, pp. 400405, 2009.

[119] F. Figeac, A. Ilias, D. Bailbe, B. Portha, and J. Movassat, "Local in vivo GSK3beta knockdown promotes pancreatic beta cell and acinar cell regeneration in 90\% pancreatectomized rat," Molecular Therapy, vol. 20, pp. 1944-1952, 2012.

[120] Ansarullah, B. Bharucha, M. Umarani et al., "Oreocnide integrifolia flavonoids augment reprogramming for islet neogenesis and beta-cell regeneration in pancreatectomized BALB/c mice," Evidence-Based Complementary and Alternative Medicine, vol. 2012, Article ID 260467, 13 pages, 2012.

[121] Y. Wang, H. Wang, Y. Liu, C. Li, P. Qi, and J. Bao, "Antihyperglycemic effect of ginsenoside Rh2 by inducing islet beta-cell regeneration in mice," Hormone and Metabolic Research, vol. 44, pp. 33-40, 2012.

[122] H. S. Jung, Y. R. Ahn, S. H. Oh et al., "Enhancement of $\beta$-cell regeneration by islet transplantation after partial pancreatectomy in mice," Transplantation, vol. 88, no. 3, pp. 354-359, 2009.

[123] T. Pearson, T. G. Markees, D. V. Serreze et al., "Islet cell autoimmunity and transplantation tolerance: two distinct mechanisms?" Annals of the New York Academy of Sciences, vol. 1005, pp. 148-156, 2003. 
[124] A. A. Rossini, J. P. Mordes, T. G. Markees, N. E. Phillips, E. J. Gordon, and D. L. Greiner, "Induction of islet transplantation tolerance using donor specific transfusion and antiCD154 monoclonal antibody," Transplantation Proceedings, vol. 31, no. 1-2, pp. 629-632, 1999.

[125] T. G. Markees, D. V. Serreze, N. E. Phillips et al., "NOD mice have a generalized defect in their response to transplantation tolerance induction," Diabetes, vol. 48, no. 5, pp. 967-974, 1999.

[126] M. Hara, C. I. Kingsley, M. Niimi et al., "IL-10 is required for regulatory $\mathrm{T}$ cells to mediate tolerance to alloantigens in vivo," Journal of Immunology, vol. 166, no. 6, pp. 3789-3796, 2001.

[127] R. D. Molano, A. Pileggi, T. Berney et al., "Long-term islet allograft survival in nonobese diabetic mice treated with tacrolimus, rapamycin, and anti-interleukin-2 antibody," Transplantation, vol. 75, no. 11, pp. 1812-1819, 2003.

[128] B. J. Hering, R. Kandaswamy, J. D. Ansite et al., "Singledonor, marginal-dose islet transplantation in patients with type 1 diabetes," Journal of the American Medical Association, vol. 293, no. 7, pp. 830-835, 2005.

[129] M. D. Bellin, F. B. Barton, A. Heitman et al., "Potent induction immunotherapy promotes long-term insulin independence after islet transplantation in type 1 diabetes," American Journal of Transplantation, vol. 12, pp. 1576-1583, 2012.

[130] A. Vergani, F. D’Addio, M. Jurewicz et al., "A novel clinically relevant strategy to abrogate autoimmunity and regulate alloimmunity in NOD mice," Diabetes, vol. 59, no. 9, pp. 2253-2264, 2010.

[131] F. Baeke, T. L. Van Belle, T. Takiishi et al., "Low doses of antiCD3, ciclosporin A and the vitamin D analogue, TX527, synergise to delay recurrence of autoimmune diabetes in an islettransplanted NOD mouse model of diabetes," Diabetologia, vol. 55, pp. 2723-2732, 2012.

[132] A. A. Mamchak, Y. Manenkova, W. Leconet et al., "Preexisting autoantibodies predict efficacy of oral insulin to cure autoimmune diabetes in combination with anti-CD3," Diabetes, vol. 61, pp. 1490-1499, 2012. 


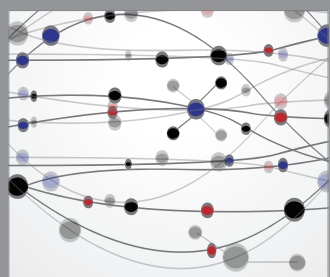

The Scientific World Journal
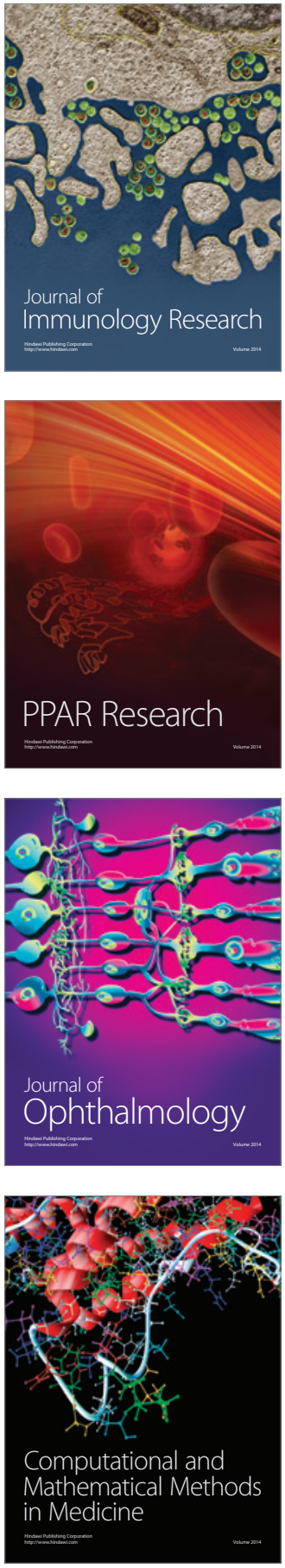

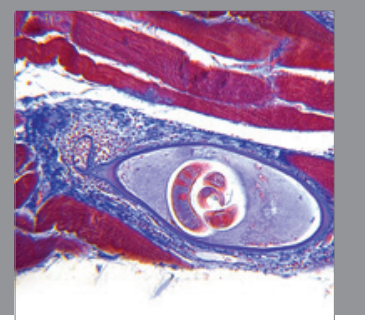

Gastroenterology

Research and Practice
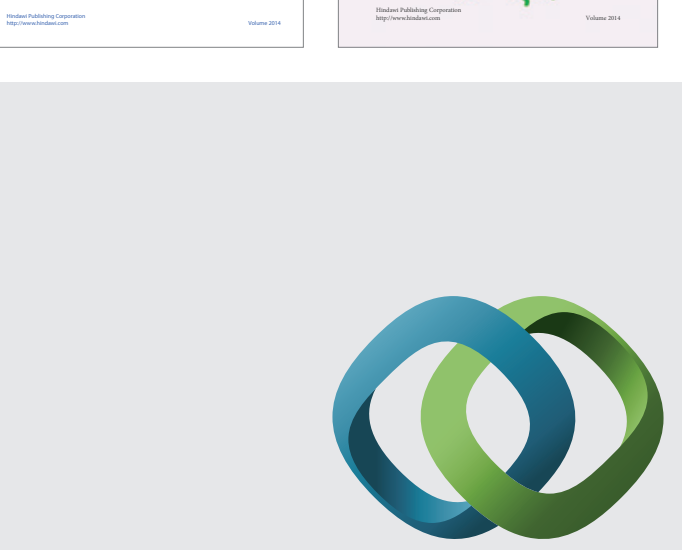

\section{Hindawi}

Submit your manuscripts at

http://www.hindawi.com
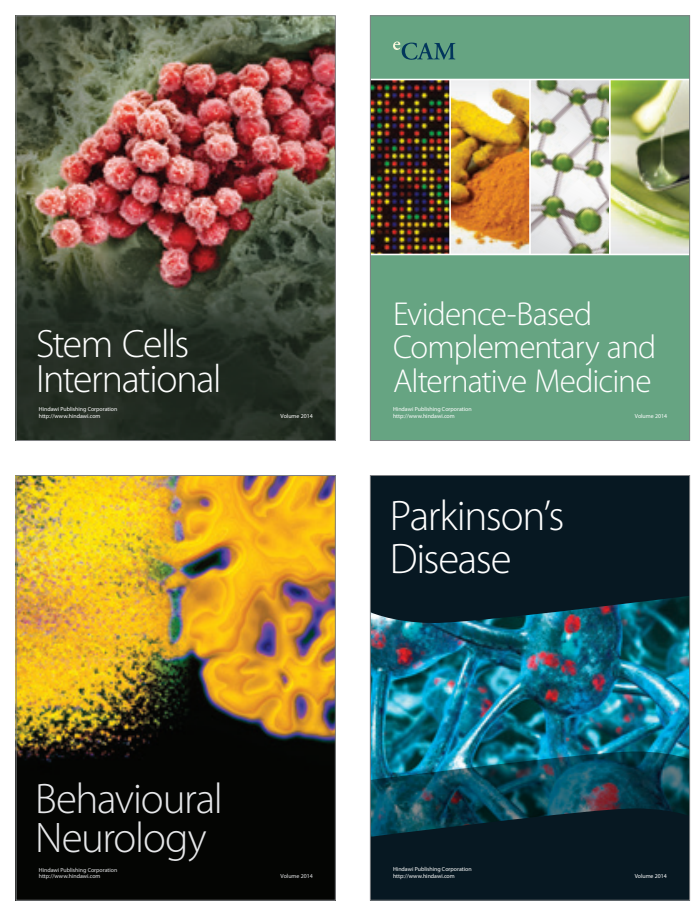

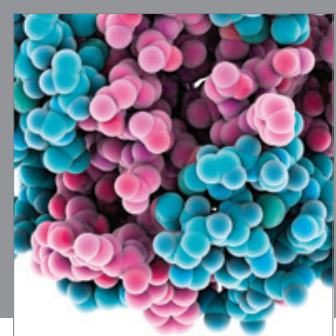

Journal of
Diabetes Research

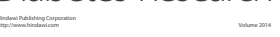

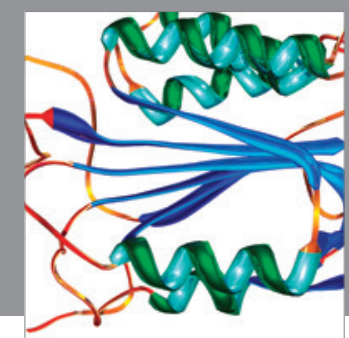

Disease Markers
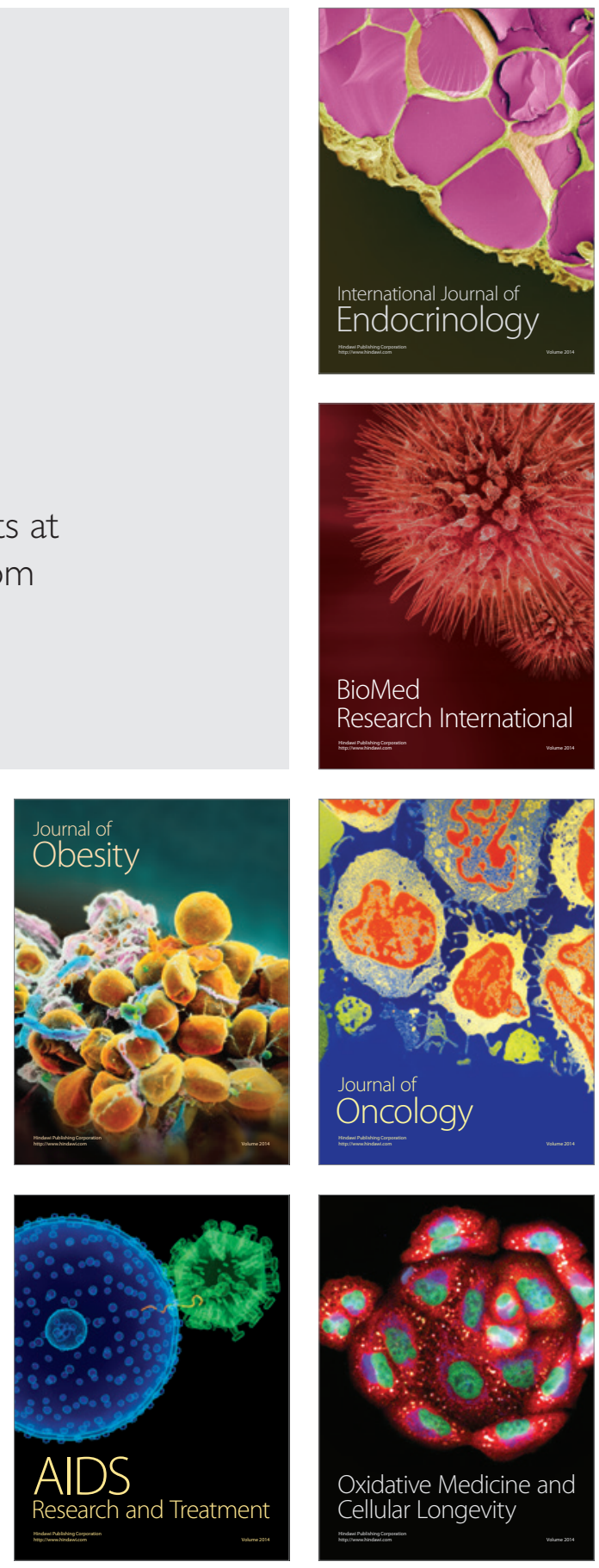